\author{
K. ShсHокina ${ }^{1}$, G. BeliK ${ }^{1}$, D. Semeniv ${ }^{2}$, V. Ulanova ${ }^{1}$
}

${ }^{1}$ National University of Pharmacy of Ukraine of the Ministry of Health of Ukraine

${ }^{2}$ Ivano-Frankivsk National Medical University

\title{
A COMPARATIVE STUDY OF THE HEPATOTROPHIC PROPERTIES OF NON-STEROIDAL ANTI-INFLAMMATORY DRUGS
}

Topicality. Recently, more and more works on the hepatotoxicity of NSAIDs have appeared in the literature. Presumably, all NSAIDs have hepatotoxicity, but the degree of adverse effects on the liver in different drugs is variable.

Aim. To study the effect of different generations of NSAIDs on the functional state of the liver of the experimental animals.

Materials and methods. Diclofenac sodium, piroxicam, indomethacin, meloxicam and celecocosib were selected for the comparative study. Changes in the functional state of the liver of intact rats during subchronic administration of the drugs selected, as well as their impact on the course of the model hepatitis were determined. The state of the liver was determined by the following indicators: the mass coefficient of the liver, the activity of alanine aminotransferase, alkaline phosphatase, the content of total protein, urea, cholesterol in the blood serum, the level of TBA-active products, diene conjugates, reduced glutathione, catalase and glycogen in the liver homogenate.

Results and discussion. It was found that diclofenac, piroxicam, indomethacin in the doses of $\mathrm{ED}_{50}$ by the antiexudative activity when used for 14 days adversely affected the liver of intact animals, as well as worsened the course of the model hepatitis, i.e. had a pronounced hepatotoxic effect. Meloxicam and celecoxib did not show a pronounced adverse effect in the carbon tetrachloride hepatitis, but contributed to the deterioration of the functional state of the liver of intact rats, i.e. had a moderate hepatotoxic effect.

Conclusions. By the level of hepatotoxicity the drugs studied can be arranged as follows: diclofenac > indomethacin > piroxicam $>$ meloxicam $>$ celecoxib.

Key words: hepatotoxicity; diclofenac sodium; indomethacin; piroxicam; meloxicam; celecoxib

К. Г. Щокіна' ${ }^{1}$, Г. В. Бєлік ${ }^{1}$, Д. В. Семенів ${ }^{2}$, В. А. Уланова ${ }^{1}$

${ }^{1}$ Національний фармацевтичний університет Міністерства охорони здоров'я України

${ }^{2}$ Івано-Франківський національний медичний університет

\section{Порівняльне дослідження гепатотропних властивостей нестероїдних} протизапальних препаратів

Актуальність. Останнім часом у літературі з'являється все більше робіт, присвячених питанням гепатоксичності НПЗП. Імовірно, всі НПЗП характеризуються гепатотоксичністю, однак ступінь негативного впливу на печінку в різних препаратів варіабельний.

Метою пропонованої роботи стало порівняльне вивчення впливу препаратів різних поколінь НПзП на функціональний стан печінки експериментальних тварин.

Матеріали та методи. Для порівняльного дослідження було обрано диклофенак натрію, піроксикам, індометацин, мелоксикам та целекоксиб. Визначали зміни функціонального стану печінки інтактних щурів за субхронічного введення обраних препаратів, а також їх вплив на перебіг модельного гепатиту. Стан печінки визначали за такими показниками: масовий коефіцієнт печінки; активність аланінамінотрансферази, лужної фосфатази, вміст загального білка, сечовини, холестеролу в сироватці крові; рівень ТБК-активних продуктів, дієнових кон'югатів, відновленого глутатіону, каталази та глікогену в гомогенаті печінки.

Результати та їх обговорення. З’ясовано, що диклофенак, піроксикам, індометацин у дозах ЕД 50 за антиексудативною активністю за застосування протягом 14-ти днів негативно впливають на стан печінки інтактних тварин, а також погіршують перебіг модельного гепатиту, тобто проявляють виражену гепатотоксичну дію. Мелоксикам і целекоксиб не виявляють вираженої негативної дії у разі тетрахлорметанового гепатиту, але сприяють погіршенню функціонального стану печінки інтактних щурів, тобто чинять помірну гепатотоксичну дію.

Висновки. За рівнем гепатоксичності порівнювані препарати можна розташувати так: диклофенак > індометацин > піроксикам > мелоксикам > целекоксиб.

Ключові слова: гепатотоксичність; диклофенак натрію; індометацин; піроксикам; мелоксикам; целекоксиб

\section{Е. Г. Щекина ${ }^{1}$, Г. В. Белик ${ }^{1}$, Д. В. Семенив ${ }^{2}$, В. А. Уланова ${ }^{1}$}

${ }^{1}$ Национальной фармацевтический университет Министерства здравоохранения Украины

${ }^{2}$ Ивано-Франковский национальный медицинский университет

Сравнительное исследование гепатотропных свойств нестероидных противовоспалительных препаратов

Актуальность. В последнее время в литературе появляется все больше работ, посвященных вопросам гепатоксичности НПВП. Вероятно, все НПВП обладают гепатотоксичностью, однако степень негативного воздействия на печень у различных препаратов вариабельна.

Целью данной работы является сравнительное исследование влияния наиболее широко применяемых НПВП разных поколений на функциональное состояние печени экспериментальных животных. 
Материалы и методы. Для сравнительного исследования были выбраны диклофенак натрия, пироксикам, индометацин, мелоксикам и целекоксиб. Определяли изменения функционального состояния печени интактных крыс при субхроническом введении избранных препаратов, а также их влияние на развитие модельного гепатита у экспериментальных животных. Состояние печени определяли по следующим показателям: массовый коэффициент печени, активность аланинаминотрансферазы, щелочной фосфатазы, содержание общего белка, мочевины, холестерина в сыворотке крови, уровень ТБК-активных продуктов, диеновых конъюгатов, восстановленного глутатиона, каталазы и гликогена в гомогенате печени.

Результаты и их обсуждение. Установлено, что диклофенак, пироксикам, индометацин в дозе ЕД50 по антиэкссудативной активности при применении в течение 14 дней негативно влияют на состояние печени интактных животных, а также ухудшают течение модельного гепатита, то есть проявляют выраженное гепатотоксическое действие. Мелоксикам и целекоксиб не проявляют выраженного негативного воздействия при тетрахлорметановом гепатите, но способствуют ухудшению функционального состояния печени интактных крыс, то есть обладают умеренным гепатотоксическим действием.

Выводы. По уровню гепатотоксичности сравниваемые препараты можно расположить так: диклофенак > индометацин > пироксикам > мелоксикам > целекоксиб.

Ключевые слова: гепатотоксическое действие; диклофенак натрия; индометацин; пироксикам; мелоксикам; целекоксиб

\section{INTRODUCTION}

Non-steroidal anti-inflammatory drugs (NSAIDs) are one of the most popular groups of drugs. According to the WHO, about $20 \%$ of the world's population regularly uses drugs of this group [1]. At the same time, NSAID-associated side effects are the subject of large-scale scientific and practical discussions and the object of numerous experimental and clinical studies. It is known that one of the main complications of this group of drugs is the development of NSAID gastropathies [2, 3]. The side effects of NSAIDs also include liver and kidney dysfunctions, hematological reactions, etc. [4, 5]. Recently in the literature there are more and more works devoted to the issues of hepatotoxicity of NSAIDs [6-8]. Experts come to the conclusion that there is an undoubted relationship between NSAIDs and hepatotoxicity. Most often, NSAID hepatopathy is manifested by the pronounced cytolytic syndrome, cholestasis syndrome, and acute hepatic failure. As for the pathogenesis of liver damage, there is no consensus on this issue at the moment. It was previously believed that the main link in the pathogenesis of hepatotoxicity was inhibition of the prostaglandin synthesis. However, recently this hypothesis has been revised $[9,10]$. In the pathogenesis of the NSAID-associated liver damage, there is blockade of the enzyme systems of the Krebs cycle and the uncoupling of oxidative phosphorylation (similar to the Reye's syndrome) in the mitochondria of hepatocytes, blockade of phosphodiesterase IV, impaired excretion of bile due to the formation of bulky complexes of NSAID metabolites with bile acids, enterohepatic treatment, as well as immunological disorders [11].

Despite the fact that the relative risk of liver damage due to the use of NSAIDs is relatively low (8-27 cases per 100 thousand patients per year), the consequences of the resulting NSAID-induced liver damage are often the most serious [12]. The problem of the hepatotoxic effect of some NSAIDs is so acute that in a number of countries these drugs are prohibited. For example, nimesulide is currently banned for use in Spain, Finland, Israel, India, Sri Lanka. In the USA, UK, Canada and Australia, the drug was not approved for registration [13].
Probably, all modern NSAIDs have hepatotoxicity; however, the degree of the negative effect on the liver is very variable. Therefore, the aim of our work was a comparative study of the effect of different generations of NSAIDs on the functional state of the liver of the experimental animals.

\section{MATERIALS AND METHODS}

Five widely used NSAIDs of different generations were selected for the comparative study, namely diclofenac sodium, piroxicam, indomethacin, meloxicam, and celecocoxib.

To determine the effect of the drugs selected on the functional state of the liver of intact rats, the latter were administered intragastrically in the dose of $\mathrm{ED}_{50}$ by the antiexudative activity for 14 days: diclofenac sodium in the dose of $8 \mathrm{mg} / \mathrm{kg}$, piroxicam - $2 \mathrm{mg} / \mathrm{kg}$, indomethacin $5 \mathrm{mg} / \mathrm{kg}$, meloxicam $-1 \mathrm{mg} / \mathrm{kg}$, celecoxib - $7 \mathrm{mg} / \mathrm{kg}[1,14]$. On Day 15, animals were removed from the experiment, their blood was collected, and the liver was removed. The condition of the liver was determined by the following indicators: the mass coefficient of liver (LMC), alanine aminotransferase (ALT), alkaline phosphatase (ALPh), total protein (TP), urea, cholesterol (ChS) in the serum; the level of TBA-active products (TBA-AP), diene conjugates (DC), reduced glutathione (RG), catalase and glycogen in the liver homogenate.

LMC was calculated by the formula:

$$
\mathrm{LMC}=\left(\mathrm{M}_{\text {liver }} / \mathrm{M}_{\text {anima }} \mathrm{l}\right) \times 100 \% \text {. }
$$

The ALT activity was determined by the ReitmanFrenkel method, AL - by the Bessel-Lowry-Brock method, the level of TP - by the biuret reaction, $\mathrm{ChS}$ - by the Ilko method (using standard biochemical kits), and the urea content - by the Menshikov method [15]. TBA-AP, DC was determined by the reaction with 2-thiobarbituric acid spectrophotometrically using the method of I. D. Steel, T. G. Garishvili, and the RG content - by the method of Beutler E. D. et al. The level of glycogen in the liver was determined by the method of Kemp and Kitz, catalase by the method of MO Korolyuk and co-authors [16]. 
We extended the comparative study of the hepatotropic effect of the drugs on the model of acute fatty liver disease - carbon tetrachloride hepatitis in rats. Tetrachloromethane hepatitis was caused by the introduction of $50 \%$ oil solution of carbon tetrachloride in the dose of $1 \mathrm{ml} / 100 \mathrm{~g}$ of the animal weight intragastrically for 2 days $[1,14]$. To determine the effect of the drugs studied on the course of the carbon tetrachloride hepatitis, the latter was administered 1 hour after the introduction of the damaging agent for 2 days. On Day 3, animals were removed from the experiment in the state of euthanasia, the liver was removed, and the blood was collected for the biochemical examination. The condition of the liver was determined by the indicators similar to those in the previous experiment and the survival of the animals.

In the case of obtaining the results in the form of the mean \pm standard mistake, the statistical significance of intergroup differences was calculated by the Student's t test, intragroup differences - by the paired Wilcoxon test; in the case of registration of the results in an alternative form - by the angular Fisher transformation.

\section{RESULTS AND DISCUSSION}

The results of the comparative study of the effect of anti-inflammatory drugs on the functional state of the liver of intact rats are presented in Tab. 1.

According to the data obtained, diclofenac showed the greatest negative impact on the functional state of the liver of healthy animals with subchronic administration (within 2 weeks). The level of cholesterol increased by 2 times compared to the intact control group. A decrease in the content of TP in the blood serum by 1.6 times indicated a decrease in the protein-synthetic function of the liver. A probable increase ALPh by 1.6 times proved the presence of cholestasis and inflammation in the liver [17]. The increase in the level of RG in the liver ho- mogenate by one and a half time was a consequence of the deterioration of the functional state of the antioxidant system of the body (AOS) of the experimental animals. Other liver parameters in the diclofenac group did not differ significantly from those in the intact control group.

The use of piroxicam also led to the deterioration of the functional state of the liver of intact animals. There was a significant increase in the content of $\mathrm{ChS}$ in the serum of animals (1.8 times higher than in the intact control group). The level of SB decreased by 1.4 times, i.e. the protein-synthetic function of the liver was suppressed. The ALPh activity increased in 1.5 times. A significant increase in the level of TBA-AP (by 1.3 times), and the tendency to increase the content of DC in the liver homogenate indicated an increase in the intensity of the processes of lipids peroxide oxidation (LPO) in the liver of animals. Compared to diclofenac, piroxicam caused a more pronounced increase in the activity of LPO processes (the content of TBA-AP in the liver homogenate increased in 1.3 times more than in the group of animals treated with diclofenac).

Under the effect of indomethacin there was a tendency to increase LMC, increase the level of ALPh by 1.4 times, reduce the content of SB (1.3 times), and increase the content of $\mathrm{ChS}$ in the serum (in 1.7 times compared to the group of intact animals). In the liver homogenate, the level of TBA-AP increased by 1.4 times compared to the same indicator in the intact control group. There was a tendency to increase the content of DC. Thus, indomethacin worsened the liver, promoted the activation of sex processes. Compared to diclofenac, indomethacin was less effective in reducing TP and increasing $\mathrm{ChS}$ in the serum, but the level of TBK-AP under the action of indomethacin increased in 1.3 times more than on the background of diclofenac.

Meloxicam and celecoxib also contributed to some extent to the deterioration of the functional state of

Table 1

\section{THE EFFECT OF THE DRUGS STUDIED ON THE FUNCTIONAL-BIOCHEMICAL} LIVER PARAMETERS OF INTACT RATS

\begin{tabular}{|c|c|c|c|c|c|c|}
\hline Parameters & $\begin{array}{c}\text { Intact control } \\
(\mathrm{n}=10)\end{array}$ & $\begin{array}{l}\text { Indometacin } \\
(\mathrm{n}=10)\end{array}$ & $\begin{array}{c}\text { Diclofenac } \\
(n=10)\end{array}$ & $\begin{array}{l}\text { Piroxicam } \\
(\mathrm{n}=10)\end{array}$ & $\begin{array}{l}\text { Meloxicam } \\
(\mathrm{n}=10)\end{array}$ & $\begin{array}{c}\text { Celecoxib } \\
(n=10)\end{array}$ \\
\hline LMC, $\%$ & $3.3 \pm 0.1$ & $3.5 \pm 0.2$ & $3.7 \pm 0.1^{*}$ & $3.6 \pm 0.2$ & $3.5 \pm 0.3$ & $2.8 \pm 0.1^{*} / * *$ \\
\hline ALT, mmol/hour x l & $0.5 \pm 0.08$ & $0.5 \pm 0.06$ & $0.6 \pm 0.02$ & $0.5 \pm 0.04$ & $0.5 \pm 0.05$ & $0.4 \pm 0.05^{* *}$ \\
\hline ALPh, mccat/l & $0.7 \pm 0.10$ & $0.9 \pm 0.08 *$ & $1.1 \pm 0.06^{*}$ & $1.0 \pm 0.05^{*}$ & $0.8 \pm 0.08^{* *}$ & $0.8 \pm 0.04^{* *}$ \\
\hline $\mathrm{ChS}, \mathrm{mmol} / \mathrm{l}$ & $1.2 \pm 0.1$ & $2.0 \pm 0.3^{*} / * *$ & $2.8 \pm 0.1^{*}$ & $2.2 \pm 0.4^{*}$ & $2.1 \pm 0.2^{*} / * *$ & $2.7 \pm 0.2^{*}$ \\
\hline \multicolumn{7}{|c|}{ Liver tissue } \\
\hline $\mathrm{DC}, \mathrm{mmol} / \mathrm{g}$ & $5.3 \pm 0.6$ & $6.4 \pm 0.8$ & $4.7 \pm 0.6$ & $6.4 \pm 0.5$ & $5.3 \pm 0.4$ & $4.9 \pm 0.7$ \\
\hline TBA-AP, $\mathrm{mmol} / \mathrm{g}$ & $103.1 \pm 10.4$ & $141.8 \pm 8.1^{*} /{ }^{* *}$ & $112.2 \pm 6.3$ & $138.6 \pm 7.7^{*} / * *$ & $108.2 \pm 6.9$ & $105.7 \pm 4.9$ \\
\hline
\end{tabular}

Notes: * deviation of the indicator is significant for the group of the intact control, $\mathrm{p}<0.05$;

** - deviation is significant for the diclofenac group, $\mathrm{p}<0.05$. 
the liver of healthy animals. Under the effect of meloxicam the level of ALPh increased (by 2 times), indicating the presence of cholestasis and inflammation in the liver. Meloxicam and celecoxib contributed to an increase in cholesterol (by 2.3 times) compared to the similar indicators in the intact control group.

Therefore, diclofenac, piroxicam, indomethacin when used for 14 days in intact animals showed a pronounced hepatotoxic effect. Meloxicam and celecoxib in the similar experimental conditions also contributed to the deterioration of the functional state of the liver. By reducing the hepatotoxic effect the drugs were arranged as follows: diclofenac $>$ piroxicam $>$ indomethacin $>$ meloxicam $\geq$ celecoxib.

We continued the comparative study of the hepatotropic effect of the drugs selected on the model of acute fatty liver disease - tetrachloromethane hepatitis in rats. The condition of the liver was determined by indicators similar to those in the previous experiment, as well as by the survival rate of animals. The results of this study are presented in Tab. 2.

In the control pathology group, the development of fatty degeneration of the liver was observed; it was accompanied by an increase in the mass coefficient of the liver by 1.8 times compared to the intact control group, indicating severe intoxication and the development of inflammation in the liver tissue under the effect of carbon tetrachloride $[1,9]$. By the end of the experiment, half of the animals died (survival was $50 \%$ ). The level of $\mathrm{ChS}$ in the blood increased in 1.8 times. The increase in the serum ChS is a compensatory reaction in the intensification of LPO processes since in hypercholesterolemia $\mathrm{ChS}$ is more easily integrated into cell membranes and stabilizes them [18].
The increased ALPh activity (by 2.6 times) suggested the presence of inflammation and cholestasis in the liver. A decrease in the protein content of liver in the blood serum of animals was by 1.3 times.

A sharp increase in the ALT activity (1.7 times comEpared to the intact control group) indicated an increase in cytolysis in the liver, which correlated with an increase in LPO processes. The decrease in the level of RG (by 1.7 times) and catalase (by 2.4 times) in the homogenate of the organ was a consequence of the suppression of AOS in animals. The antitoxic function of the liver was also suppressed, as evidenced the increased level of urea in the serum of control animals. The content of glycogen in the liver decreased in 2 times, indicating a decrease in the synthetic function of the liver.

The drugs affected the severity of the pathological process in the liver to varying degrees. The use of indomethacin did not reduce the hepatotoxic effect of carbon tetrachloride, on the contrary, a significant increase in the content of TBA-AP (by 1.2 times), DC (by 1.1 times) decreased the level of RG in the liver homogenate (by $1.2 \mathrm{ti}$ mes) compared to the similar indicators in animals of the control pathology group. However, the introduction of indomethacin contributed to a significant reduction in the ALT activity in the liver homogenate (by 1.2 times) and the level of cholesterol in the blood (by 3.6 times). The survival of the animals increased by one and a half time compared to the control pathology group and was $75 \%$.

Diclofenac did not also reduce the hepatotoxic effect of carbon tetrachloride. There was a significant increase in relation to the control pathology, the content of $\mathrm{ChS}$ in the serum increased by 1.3 times. The introduction of

Table 2

\section{THE EFFECT OF THE DRUGS ON THE FUNCTIONAL AND BIOCHEMICAL PARAMETERS OF THE LIVER IN THE CARBON TETRACHLORIDE HEPATITIS IN RATS}

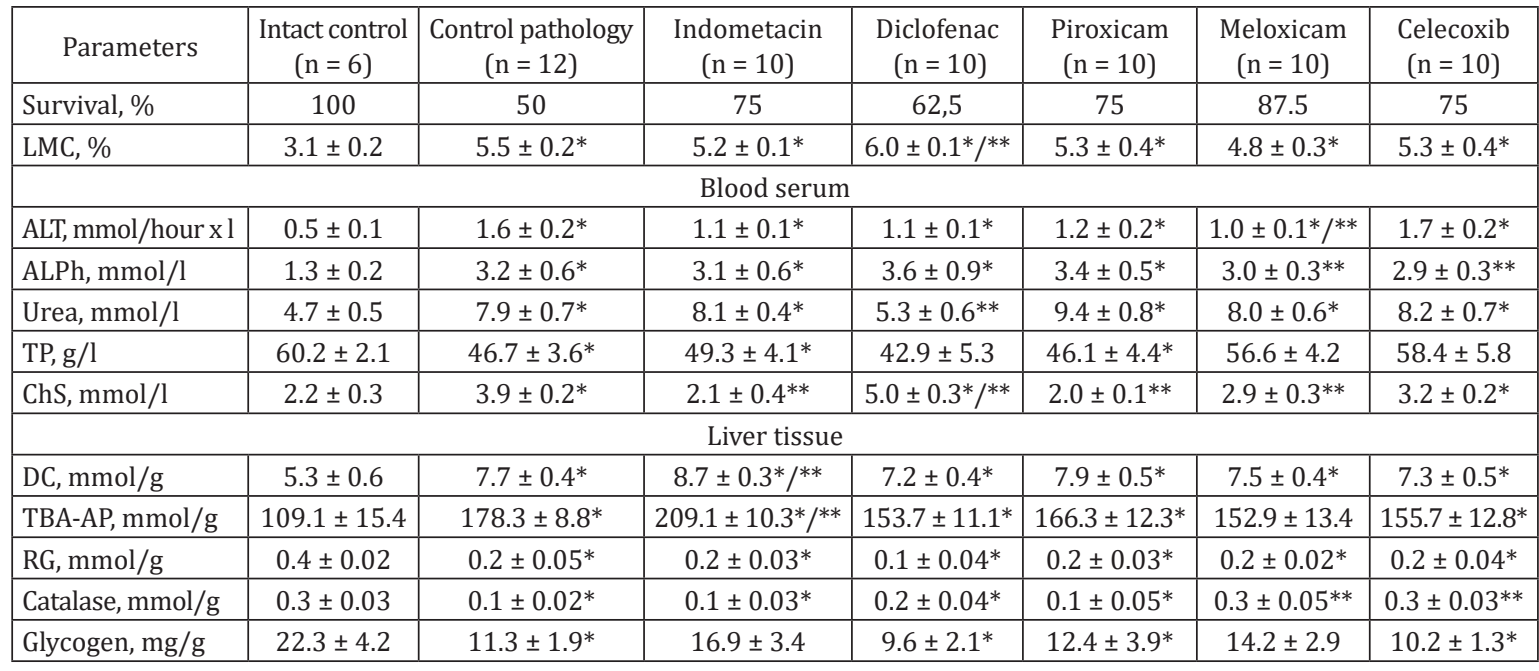

Notes: ${ }^{*}$ - deviation of the indicator is significant for the group of the intact control, $\mathrm{p}<0.05$; ${ }^{* *}$ - deviation of the indicator is significant for the group of the control pathology, $\mathrm{p}<0.05$. 
the drug helped to reduce the content of TBK-AP, but the level of RG decreased by 1.7 times. The survival of the animals was $62.5 \%$ (less than in the group of animals receiving indomethacin, but more than in the group of he control pathology).

In the group of animals treated with piroxicam, there was a tendency to increase LMC compared to the control pathology group. There were significantly increased urea levels in the serum of animals, indicating a decrease in the antitoxic (ammonia-detoxifying) function of the liver. However, the introduction of piroxicam significantly reduced the activity of ALT (in 1.2 times), i.e. there was a tendency to reduce cytolytic processes in the liver. The survival of rats was $75 \%$

Against the background of the introduction of meloxicam, there was a decrease in MCP (decreased in 1.2 times compared to the control pathology group), the marker of ALT cytolysis decreased in 1.3 times, the serum cholesterol decreased in 1.35 times. A significant increase in TP in the blood serum by 1.2 times indicated a tendency to improve the protein-synthetic function of the liver. The impact on the processes of LPO can be judged by reducing the content of TBK-AP by 1.2 times. The survival was $87.5 \%$.
The use of celecoxib contributed to the reduction of inflammatory processes and cholestasis in the liver (the level of ALPh in the serum decreased by 1.3 times, the total protein content increased by 1.3 times). Under the effect of the drug the level of LPO decreased (the content of TBA-AP in the homogenate of the organ decreased by 1.2 times). The survival was $75 \%$.

Thus, during the experiment it was found that diclofenac, piroxicam, indomethacin in the doses of $\mathrm{ED}_{50}$ by the antiexudative activity when used for 14 days adversely affected the liver of intact animals, as well as worsened the course of the model hepatitis, i.e. had a pronounced hepatotoxic effect. Meloxicam and celecoxib did not show a pronounced adverse effect in the carbon tetrachloride hepatitis, but contributed to the deterioration of the functional state of the liver of intact rats, i.e. had a moderate hepatotoxic effect.

\section{CONCLUSIONS}

By the level of hepatotoxicity the drugs studied can be arranged as follows: diclofenac > indomethacin > piroxicam $>$ meloxicam $>$ celecoxib.

Conflict of interests: authors have no conflict of interests to declare.

\section{REFERENCES}

1. Щокіна К. Г. Експериментальне обгрунтування раціонального вибору сучасних і перспективних препаратів 3 протизапальною дією : дис. ... канд. фармац. наук : Харків, 2006. 202 с.

2. Биккинина Г. М., Сафуанов А. Р. Нежелательные лекарственные реакции нестероидных противовоспалительных препаратов. Молодой ученый. 2015. № 7 (87). C. 269-272. URL: https://moluch.ru/archive/87/16884/.

3. Рациональное применение нестероидных противовоспалительных препаратов (НПВП) в клинической практике. Клинические рекомендации. / А. Е. Каратеев и др. Современная ревматология. 2015. Т. 9, № 1. C. 4-23. DOI: https://doi.org/10.14412/1996-7012-2015-1-4-23.

4. Штрыголь С. Ю. Фармакологические свойства и проблемы безопасности применения НПВП - селективных и специфических ингибиторов циклооксигеназы-2. Провизор. 2005. № 2. С. 37-42.

5. Rostom A., Goldkind L., Laine L. Nonsteroidal Anti-Inflammatory Drugs and Hepatic Toxicity: A Systematic Review of Randomized Controlled Trials in Arthritis Patients. Clinical gastroenterology and hepatology. 2005. Vol. 3, Iss. 5. P. 489-498. DOI: https://doi.org/10.1016/S1542-3565(04)00777-3.

6. Sriuttha P., Sirichanchuen B., Permsuwan U. Hepatotoxicity of Nonsteroidal Anti-Inflammatory Drugs: A Systematic Review of Randomized Controlled Trials. International Journal of Hepatology. 2018. Vol. 1. P. 1-13. DOI: https://doi.org/10.1155/2018/5253623.

7. Meunier L., Larrey D. Recent Advances in Hepatotoxicity of Non Steroidal Anti-inflammatory Drugs. Annals of Hepatology. 2018. Vol. 17, Iss. 2. P. 187-191. DOI: https://doi.org/10.5604/01.3001.0010.8633.

8. Liver injury from nonsteroidal anti-inflammatory drugs in the United States. Liver Int Off / P. A. Schmeltzer et al. Liver international. 2016. Vol. 36, Iss. 4. P. 603-609. DOI: https://doi.org/10.1111/liv.13032.

9. Современные представления о механизмах терапевтического и побочного действия НПВС / В. Мамчур и др. Вісник фармакології та фармації. 2005. № 4. С. 3-17.

10. Рациональное применение НПВП-баланс эффективности и безопасности : обзор литературы / М. В. Журавлева и др. Международный журнал прикладных и фундаментальных исследований. 2016. № 6, Ч. 4. С. 687-696.

11. Hepatotoxicity and Changes in Liver Enzymes Due to Use of Non-Steroidal Anti Inflammatory Drugs (NSAIDs) in Non-Traumatic Musculoskeletal Painful Disorders / S. Nicose et al. Molecular Enzymolody and drug targets. 2015. Vol. 1, Iss. 2-3. P. 1-6. DOI: https://doi.org/10.21767/2572-5475.10007.

12. Wiley F. NSAID-Induced Hepatotoxicity Rare, but Still Important to Note. Drug Topics Journal. 2020. Vol. 164, Iss. 4. P. 20.

13. A comprehensive review of nonsteroidal anti-inflammatory drug use in the elderly / S. Wongrakpanich et al. Aging Disease. 2018 . Vol. 9, Iss. 1. P. 143-150. DOI: https://doi.org/10.14336/AD.2017.0306.

14. Руководство по экспериментальному (доклиническому) изучению новых фармакологических веществ / под ред. Р. У. Хабриева. 2-е изд. перераб. и доп. Москва : Медицина, 2005. 832 с.

15. Камышников В. С. Справочник по клиническо-биохимической лабораторной диагностике : в 2 т. Минск : Беларусь, 2002. Т. 1.495 с. ; T. $2.463 \mathrm{c}$.

16. Арутюнян А. В., Дубина Е. Е. Методы оценки свободно-радикального окисления и антиоксидантной системы организма : метод. рек. Санкт-Петербург : Фолиант, 2000. 104 c

17. Larrey D., Ursic-Bedoya J., Meunier L. Drug-Induced hepatotoxicity. In: Schiff ER, editor. Schiff 's diseases of the liver. 12th ed. New York: WileyBlackwell, 2018. P. 740-773.

18. Drug-induced liver injury: Interactions between drug properties and host factors / M. Chen et al. Journal of Hepatology. 2015. Vol. 63, Iss. 2. P. 503-514. DOI: https://doi.org/10.1016/j.jhep.2015.04.016. 


\section{REFERENCES}

1. Shchokina, K. H. (2006). Eksperymentalne obgruntuvannia ratsionalnoho vyboru suchasnykh i perspektyvnykh preparativ z protyzapalnoiu diieiu. Candidates thesis. Kharkiv, 202.

2. Bikkinina, G. M., Safuanov, A. P. (2015). Undesirable drug reactions of non-steroidal anti-inflammatory drugs. Young scientist, 7 (87), 269-272 Available at: https://moluch.ru/archive/87/16884/.

3. Karateev, A. E., Nasonov, E. L., Yakhno, N. N., Ivashkin, V. T. (2015). Sovremennaia revmatolohyia, 9 (1), 23. doi: https://doi.org/10.14412/19967012-2015-1-4-23.

4. Shtrygol, S. Yu. (2005). Provizor, 2, 37-42.

5. Rostom, A., Goldkind, L., Laine, L. (2005). Nonsteroidal Anti-Inflammatory Drugs and Hepatic Toxicity: A Systematic Review of Randomized Controlled Trials in Arthritis Patients. Clinical gastroenterology and hepatology, 3 (5), 489-498. doi: https://doi.org/10.1016/S1542-3565(04)00777-3

6. Sriuttha, P., Sirichanchuen, B., Permsuwan, U. (2018). Hepatotoxicity of Nonsteroidal Anti-Inflammatory Drugs: A Systematic Review of Randomized Controlled Trials. International Journal of Hepatology, 1, 1-13. doi: https://doi.org/10.1155/2018/5253623.

7. Meunier, L., Larrey, D. (2018). Recent Advances in Hepatotoxicity of Non Steroidal Anti-inflammatory Drugs. Annals of Hepatology, 17 (2), $187-191$. doi: https://doi.org/10.5604/01.3001.0010.8633.

8. Schmeltzer, P. A., Kosinski, A. S., Kleiner, D. E., Hoofnagle, J. H., Stolz, A., Fontana, R. J., Russo, M. W. et al. (2016). Liver injury from nonsteroidal antiinflammatory drugs in the United States Liver Int OffJ Int Assoc Study Liver, 36, 603-609. doi: https://doi.org/10.1111/liv.13032.

9. Mamchur, V., Podpletnia, E., Makarenko, O. et al. (2005). Visnyk farmakolohii ta farmatsii, 4, 3-17.

10. Zhuravleva, M. V., Kukes, V. G., Prokofiev, A. B., Serebrova, S. Yu., Horodetskaia. G. I., Berdnikova. N. H. (2016). Mezhdunarodnyi zhurnal prikladnykh i fundamentalnykh issledovanii, 6 (4), 687-696.

11. Nicose, S., Arora, M., Singh, P. K. (2015). Hepatotoxicity and Changes in Liver Enzymes Due to Use of Non-Steroidal Anti Inflammatory Drugs (NSAIDs) in Non-Traumatic Musculoskeletal Painful Disorders. Molecular Enzymolody and drug targets, 1 (2-3), 1-6. doi: https://doi.org/10.21767/2572-5475.10007. 12. Wiley, F. (2020). NSAID-Induced Hepatotoxicity Rare, but Still Important to Note. Drug Topics Journal, 164 (4), 20

13. Wondrakpanich, S., Wongrakpanich, A., Melhado, K., Rangaswami, J. (2018). A comprehensive review of nonsteroidal anti-inflammatory drug use in the elderly. Aging Dis., 9 (1), 143-150. doi: 10.14336/AD.20170306.

14. Khabriev, R. U. (Ed.). (2005). Rukovodstvo po eksperimentalnomu (doklinicheskomu) izucheniiu novykh farmakologicheskikh veshchestv. $2^{\text {nd }}$ ed. Moscow: Meditcina, 832

15. Kamyshnikov, V. S. (2002). Spravochnik po klinichesko-biokhimicheskoi laboratornoi diagnostike. (Vols. 1-2). Minsk: Belarus.

16. Arutiunian, A. V., Dubina, E. E. (2000). Metody otcenki svobodno-radikalnogo okisleniia i antioksidantnoi sistemy organizma. Saint Petersburg. Foliant, 104.

17. Larrey, D., Ursic-Bedoya, J., Meunier, L. (2018). Drug-Induced hepatotoxicity. Schiff 's diseases of the liver. E. R. Schiff (Ed.). 12 ${ }^{\text {th }}$ ed. New York: Wiley- Blackwell, 740-773.

18. Chen, M., Suzuki, A., Borlak, J., Andrade, R. J., Lucena, M. I. (2015). Drug-induced liver injury: Interactions between drug properties and host factors Journal of Hepatology, 63 (2), 503-514. doi: https://doi.org/10.1016/j.jhep.2015.04.016

\section{Information about authors:}

Shchokina K., Doctor of Medicine (Dr. habil.), professor of the Pharmacology Department, National University of Pharmacy of Ukraine of the Ministry of Health of Ukraine. ORCID: http://orcid.org/0000-0003-3297-5999

Belik G., associate professor of the Pharmacology Department, National University of Pharmacy of Ukraine of the Ministry of Health of Ukraine. ORCID: http://orcid.org/0000-0001-7207-2036

Semeniv D., Doctor of Medicine (Dr. habil.), professor of the Department of Organization and Economics of Pharmacy and Drug Technology, Ivano-Frankivsk National Medical University

Ulanova V., Candidate of Pharmacy (Ph.D.), associate professor of the Pharmacology Department, National University of Pharmacy of Ukraine of the Ministry of Health of Ukraine. ORCID: http://orcid.org/0000-0002-0654-4872

Відомості про авторів:

Щокіна К. Г., докторка мед. наук, професорка кафедри фармакології та фармакотерапії, Національний фармацевтичний університет Міністерства охорони здоров'я України. ORCID: http://orcid.org/0000-0003-3297-5999

Бєлік Г. В., кандидатка фарм. наук, доцентка кафедри фармакології та фармакотерапії, Національний фармацевтичний університет Міністерства охорони здоров'я України. ORCID: http://orcid.org/0000-0001-7207-2036

Семенів Д. М., доктор фарм. наук, професор кафедри організації та економіки фармації і технології ліків, Івано-Франківський національний медичний університет. ORCID: https://orcid.org/0000-0001-9285-625X

Уланова В. А., кандидатка фарм. наук, доцентка кафедри фармакології та фармакотерапії, Національний фармацевтичний університет Міністерства охорони здоров'я України. ORCID: http://orcid.org/0000-0002-0654-4872

Сведения об авторах:

Щекина Е. Г., доктор мед. наук, профессор кафедры фармакологии и фармакотерапии, Национальный фармацевтический университет Министерства здравоохранения Украины. ORCID: http://orcid.org/0000-0003-3297-5999

Белик Г. В., кандидат фарм. наук, доцент кафедры фармакологии и фармакотерапии, Национальный фармацевтический университет Министерства здравоохранения Украины. ORCID: http://orcid.org/0000-0001-7207-2036

Семенив Д. В., доктор фарм. наук, профессор кафедры организации и экономики фармации и технологии лекарств, Ивано-Франковский национальный медицинский университет. ORCID: https://orcid.org/0000-0001-9285-625X

Уланова В.А. , кандидат фарм. наук, доцент кафедры фармакологии и фармакотерапии, Национальный фармацевтический университет Министерства здравоохранения Украины. ORCID: http://orcid.org/0000-0002-0654-4872

Надійшла до редакції 24.01.2021 р. 